\title{
Otherness: Between Vilifying and Dignifying
}

\author{
Chakour Khaoula \\ $\mathrm{PhD}$ student in Interactions in Literature, Culture and Society, \\ Sultan Moulay Slimane University, Beni Mellal, Morocco
}

\begin{abstract}
Otherness is an intricate concept which is at the core of human ontology. In fact, this alterity is very substantial in the processes of self-identification and identity formation. Nonetheless, otherness has always been subjected to variegated essentialist and vilifying modes of representation and interpretation in furtherance of a hegemonic discourse of violence. Hence, representing otherness, namely racial otherness, cultural otherness, gendered otherness and epistemic otherness becomes in many instances engrafted within the dehumanizing framework of "othering". In this regard, abiding by the Levinasian logic and by Irigaray's philosophy of difference, it is possible to entrench an ethical, human relation with Otherness.
\end{abstract}

Keywords: Otherness, othering, representation, difference, discourse.

DOI: $10.7176 /$ JLLL/57-06

Publication date: June $30^{\text {th }} 2019$

\section{Introduction}

Otherness or alterity is an intricate concept which is intrinsically bound up with human existence and is underlying in one way or another a plethora of human discourses. Indeed, otherness can be defined as a critical and philosophical concept which signals the state or condition of being "other" with the latter term referring to "anyone who is separate from one's self" (Ashcroft et al., 2007, p. 154). More importantly, otherness is drastically vital in informing one's existence. In other words, according to Levinas, when the self encounters the other, the I knows itself not in its self-sameness but in its difference from this otherness (Wolfreys et al., 2006, p. 6). Therefore, otherness is indispensable in the processes of self-identification and identity formation. However, granted a central position in the world because of its economic and political power, the Eurocentric and essentialist Western thought has fomented up to this day a privileged position of this Western, deemed "perfect", Self as opposed to the non-Western other. In fact, the latter is invariably engrafted within an essentializing framework of representation as well as subjected to a plurality of interpretations, and this is what is assembled under the umbrella term of "othering". In point of fact, representing otherness, more particularly racial otherness, cultural otherness, gendered otherness and epistemic otherness, is primarily incarnated in this denigrating and dehumanizing process of othering which reveals a misinterpretation of alterity through its multifarious instances, and aims, thus, at inflicting all types of violence on this other. Probably, in order to remove the barriers between the self and the other and perceive the latter in human terms, it is of paramount utility to resort to Levinas's conception of otherness and to adopt Irigaray's theory of difference.

An examination of the manifold representations of otherness by means of the othering process entails a brief glimpse at this requisite notion. As a matter of fact, the term othering was first coined by Gayatri Spivak to refer to the process whereby a hegemonic discourse- in her case the imperial discourse- creates its "others" (Ashcroft et al., 2007, p. 156). Besides, it can be asserted that othering is a dehumanizing and reifying process which takes different forms and manifestations so as to perpetuate the perennial hegemony of its discourse and to uphold its ideology of violence and domination. In this regard, it is worth mentioning that this process implements two focal strategies, stereotyping and Manichean binarism, in pursuance of its hegemonic ideologies of violence.

\section{Racial Otherness:}

To get started with, it is irrefragably of the essence to elaborate on the representational othering of racial alterity. In fact, human beings are potently inclined to identify themselves as uniquely different on the basis of race, creating, thus, a racial other for themselves. This was formerly implemented through the contrivance of such sciences as ethnology, physiognomy and phrenology, all being racial theories which delineate the boundaries primarily between this white self and its counterparts. In this respect, representing this racial other occurs most notably through othering based on stereotypical foundations like the trope of the "vampire". This gothic vignette was basically implemented within the Victorian fin-de-siècle English literary and political discourses in an endeavor of othering the Irish people given their racial difference. This link between the Irishman and the English creation -the vampire- was corroborated through the physiognomic studies of the time which advanced that people with prognathous jaws, as vampires, belonged to a lower level of civilizational development; this physiognomic conception matched to a great extent the prevalent stereotypical perception of the Irish people as having increasingly prognathous jaws (Tynan, 2010, p. 4). Probably, the most famous account on vampires is 
Stoker's Dracula which depicts Count Dracula as an abnormal being with protruding jaws and hairy hands, awfully pale, blood-sucking, contagious and endowed with a criminal and evil mind. This vampiric image was intended to congruously match the stereotypes that were prevalent about the Irish people as primitive, simian people with fang-like teeth as well as disease carriers (Tynan, 2010, p. 5). In fact, the gothic novel of Stoker, as an Irish author privileged of having been one of the denizens of the English metropolis, can be envisioned as an attempt to lay bare the stereotypical othering of this Irish alterity given that he was granted a better knowledge about the way the English represent or rather "misrepresent" their racial counterparts -the Irish- in political cartoons and literature. However, it can be extrapolated that one of the outstanding facts about this English othering is that it emanates not from the recognition of the English of their difference from the colonial Irish subjects, but rather from their fear and galvanization at facing their white sameness. Hence, the process of othering sometimes issues from an innate fear of facing one's self-sameness, and this is best typified through the invisible otherness of Count Dracula which is evident through his insinuation within the English society without being noticed as a vampiric other (Tynan, 2010, p. 1). Finally, one may ask why this othering comes into manifestation. Certainly, the most plausible answer is the justification of the English occupation and the political domination of Ireland. So, this misshapen representation of otherness evidences that it is just a catalyst rationalizing all types of violence against the Irish.

In the same racial fashion, the European thought has so long advocated the prerogative assigned to the white race and absolutized the supremacy of the Western culture, which has instigated a vilifying gaze to every non-white race especially when talking about "blacks". And here again a process of racial othering is initiated in its most quintessential forms: the cannibal. It is true that the Enlightenment came up with a new perspective visà-vis black people as what is known as the "noble savage", yet the justification of imperial projects in African nations necessitated the rebuttal of this concept and the invention of a denigrating and demoting image of the African natives. Correspondingly, the stereotype of the cannibal emerged as the utmost savagery, atavism and cruelty of this black other as opposed to the civilized, knowledgeable and developed European Self. As is the case with the stigmatization of the Irish people, the racial othering of black people is also meant to wield control over them as Kilgour claims: "cannibalism is a conventional satirical topos, which has been traditionally used for political purposes to demonize and attack forces seen as threatening” (Piatti-Farnell, 2010, p. 9). Friday, for instance, in Robinson Crusoe, with his cannibalistic past, is rendered an easy target for Robinson's domination, which substantiates the political motives of this racial othering.

\section{Cultural Otherness:}

Moreover, the process of othering may surface when it comes to the encounter between two discrepant cultures involved in an asymmetric relation of power. This is the case of the Oriental culture which has long been the object of the process of European othering. In fact, Europeans find it a weighty exigency to create the Oriental as 'other' so that they "can define [themselves] and strengthen [their] own identity by invoking such a juxtaposition" (Ashcroft and Ahluwalia, 2001, p. 64); that is to say, the Western moral and cultural supremacy is made possible only by othering the Oriental in terms of a myriad of manichean binaries. In this respect, in his magnum opus Orientalism, Said evinces that the Orientalist discourse assays to erect this cultural other as inferior, primitive, irrational, exotic, childish and feminine, whereas the European self is elevated into this superior, civilized, rational and masculine paradigm. Certainly, by having recourse to the procedure of othering, the essence of this discourse betrays its own nature and incentives: it is a pre-colonial discourse contrived for the sole objective of erecting a solid ground for the colonization of the Orient. Again, inscribing the oriental otherness within this Western system of cultural othering is not carried out haphazardly; rather, it aims at rationalizing violence, which materializes in the colonial enterprise, against Orientals. In Wyndham Lewis's Journey into Barbary, one may notice the recurrent depiction of Moroccans, as Oriental subjects, as backward and unable to administer their own affairs, and this is subsequently sealed by the authorial promotion of French colonization.

\section{Gendered Otherness:}

In addition, one of the most prominent manifestations of the representation of otherness can be readily grasped through the construction of women as "other"; it is, therefore, a gendered otherness. Indeed, many feminist and poststructuralist critics have dedicated their efforts to ransack the phallocentric construction of the woman as a subaltern Other. Probably, the most instrumental pioneer with respect to this issue is the French feminist Simone de Beauvoir (1935) who devotes her book The Second Sex to elucidate how the position of women is at stake due to the process of othering which engenders an imbalanced, dichotomic male self/female other hierarchy built on a variety of essentializing, binary oppositions. More importantly, it seems that the nucleus of de Beauvoir's theory stems from her claim that woman "is defined and differentiated with reference to man and not he with reference to her; she is the incidental, the inessential as opposed to the essential. He is the Subject, he is the Absolute- she is the Other" (De Beauvoir, 1935, p. 16). Thus, it can be inferred that the patriarchal discourse is 
invariably suffused with this proclivity to envision woman as inferior to and dependent on man while the latter is recurrently represented as the most supreme ontological entity. As a matter of fact, this is enabled through the antagonistic features which society has allotted to each gender. De Beauvoir asserts that, through othering, man is portrayed as this central, absolute, transcendent and intellectual subject, whereas woman is pictured as this marginal, unquestionably obsequious, mutilated and sensual object. Accordingly, it is the man who shapes and frames society according to his own ideology while the woman is ineluctably granted a subservient position in which she cannot but act passively and acquiesce with the patriarchal precepts. Likewise, in his attempt to showcase this gendered hierarchy established between man and woman, Jacques Derrida transposes the traditional dilemma between writing and speech to the affinity between the two genders. In this regard, man, or what Derrida terms "father", is paralleled to speech as a privileged linguistic conception interpreted as presence. Conversely, woman is equated with writing which, in the Derridean logic, is conceptualized as "weakened speech" and squarely has a nexus to absence (McGlynn, 2010, p. 5). This antithetical relation between woman as writing and absence, on the one hand, and man as speech and presence, on the other hand, results in crystallizing and buttressing the patriarchal jurisdiction. Thence, it can be inferred that the ultimate objective of othering in this gendered framework is the perpetuation of patriarchal hegemony and domination over women, with the latter reduced into mere catalytic objects of the patriarchal ethos, whose voices are thoroughly silenced.

\section{Epistemic Otherness:}

Furthermore, the self displays a great predilection to egocentrically distance himself or herself from an other who does not attain his or her same advanced epistemological level. That's why, this epistemic other becomes approached in derogatory and underestimating terms, provoking, as a result, another instance of othering. In this regard, in his "Jameson's Rhetoric of Otherness and the "National Allegory",, Aijaz Ahmad (1987) criticizes Jameson for falling in the trap of epistemic othering as he asserts: "Difference between the first world and the third is absolutized as an Otherness" (p. 10). In other words, Jameson's manichean discourse implicates an essentializing binarism between "first world" and "third world" whereby the latter is epistemologically othered and engrafted within the Hegelian master/slave dichotomy as the lower extreme. In fact, this paper purports to perceive this othering as "epistemic" given that Jameson's discourse opts for the denigration of the most momentous epistemological facet of this West's other: third world literature. Indeed, Jameson demonstrates a strong disposition to reduce the third world epistemic institution of literature into a mere monolithic and homogeneous body of national allegories through his perennial claim: "all third-world texts are necessarily [...] to be read as [...] national allegories" (as cited in Aijaz, 1987, pp. 5-6) unlike the Western or first-world literature which exults in this highly estimated and advanced world of postmodernism. Besides, unlike the widely renowned and grand classics of Joyce or Dickens, Jameson takes a firm stand on characterizing thirdworld literature as "non-canonical"; put differently, however skillfully woven these texts may be or in whatever language they may be contrived, they remain far below the Western literary canon. Evidently, it can be strongly assumed that Jameson engages in a reductionist, vilifying epistemic othering of the third world in favor of underpinning the Western epistemological supremacy and the asymmetry between the "first" and "third" worlds for the sake of maintaining the neo-imperial mechanism.

\section{Towards an Ethical, Humanitarian Self-Other Relation:}

In the light of all these essentialist and reductionist instances of this othering system of representing otherness and its ensuing implications, it may be most expedient to have recourse to the work of the philosopher of otherness, Emmanuel Levinas, so that the other could be positively assimilated by the self and the disparities between these two existential entities could be managed. As a matter of fact, in his compendium of essays Alterity and Transcendence, Levinas criticizes the Western metaphysical tradition for its propensity to focalize human existence on the primacy of the self and, instead, evinces that there is solely one construction which should be set as fundamentally prior to any ontological structure; it is that of ethics. Levinas goes further to pinpoint the nature of this ethical structure by elaborating on its umbilical reliance on an absolute and irreducible relation with the other. Besides, this self-other relationship is predicated on the perception of this other in humanitarian terms, not as an "object" over which the self can wield power or as a "thing" to be desired but rather as "someone" who " cannot be 'possessed' in the fashion in which a thing can be" (Edgar and Sedgwick, 2002, p. 138). Most importantly, in order to fulfill this ethical existence, true transcendence should be pursued with regard to the other; that is to say, once in the face-to-face encounter with the other, the power of the self should be questioned and confined through the latter's search for and "welcoming" of that which transcends his or her own existential and cognitive realm, that is, this exterior other. This welcoming entails actually " $a$ subjectivity in crisis", that is, a negation of the freedom of the self's subjectivity (Levinas, 1999, p. xiv) in pursuance of the transcendence necessary to access this ethical scope. Finally, this negotiation between the self and the other can only be realized through the self's involvement in a linguistic discourse with the other. Overall, what is to be inferred is Levinas's persistent emphasis on an irreducible, dialogic and transcendent relation with 
the other, in which the latter is positively placed above the self and humanly highly regarded, for the sake of actualizing the most sublime ontological form: ethics.

Equally important, Luce Irigaray deplores the Western philosophy and thought as being purely phallogocentric. So as to pervert this patriarchal hegemony, she calls for a philosophy of difference which she terms "sexuate difference" and which "she regards as the most basic and universal difference" (Ryan, 2010, p. 3). In fact, Irigaray believes that the liberation of humanity can be carried out through human relationships, more particularly those prevailing between man and woman. Hence, it is the "surfacing" of a distinct feminine subjectivity beside the masculine subjectivity, by dint of this "sexuate difference", which allows the confirmation and assimilation of other human differences. In this sense, Irigaray's theory of difference "transcends the masculine and feminine and includes race, age, ethnicity etc" (Ryan, 2010, p. 3). More importantly, Irigaray goes further to take a firm stand on the fact that the other should never be looked at as a thing or be reduced into an "object of study" (Ryan, 2010, p. 4). In this context, Ryan proffers the instance of Carney's movie Once as a prototypal approach of the other predicated on Irigaray's philosophy of difference. This movie is deemed Irigarayan in the sense that it showcases the story of two distinct subjectivities, Guy and Girl, who are different as far as their gender, race, culture and class are concerned, but each of the two - by means of his life in the world of music- "avoids the desire to assimilate the other into one's own existence denying him/her a unique subjectivity" (Ryan, 2010, p. 14).

\section{Conclusion:}

To conclude, Otherness is an umbrella term which subsumes a wide array of "others" ranging from the racial to the cultural, the gendered and the epistemic others. However, it can be substantiated that what is at stake is the fact that the human self is intrinsically inclined towards this will and desire to power and mastery over a different "non-self". Hence, the self finds him/herself compelled to rationalize the violence vis-à-vis this other through representational discourses predicated on this dehumanizing process of othering. Yet, in Levinasian logic, the other- this drastically intricate concept- is conceived of as a transcendental "infinity". Hence, however enormous the endeavor to other this "other", the latter remains unintelligible and transcendental of the self's grasp, which necessarily requires the resort to another stance with regard to this other- a stance which is far removed from this denigrating process of othering- for the sake of comprehending him/her. Following Irigaray's critical philosophy of difference which hinges on perceiving the other as a different subjectivity not to be assimilated into one's existence, it seems quite instrumental to strive to make real JanMohamed's words: "Genuine and thorough comprehension of Otherness is possible only if the self can somehow negate or at least severely bracket [his] values, assumptions, and ideology" (JanMohamed, 2003, p. 18).

\section{References}

Aijaz, A. (1987). Jameson's Rhetoric of Otherness and the "National Allegory". Social Text, 17, 3-25. [Online] Available: www.jstor.org/stable/466475.

Ashcroft, B., \& Ahluwalia, P. (2001). Edward Said. London: Routledge.

Ashcroft, B., Griffiths, G. \& Tiffin, H. (2007). Postcolonial Studies: The Key Concepts. London: Routledge.

De Beauvoir, S. (1953). The Second Sex. Great Britain: Jonathan Cape.

Edgar, A., \& Sedgwick, P. (2002). Levinas Emmanuel. Cultural Theory: The Key Thinkers. London: Routledge. $133-140$

JanMohammed, A. R. (2003). The Economy of Manichean Allegory. In B. Ashcroft, G. Griffiths \& H. Tiffin (Eds.), The Postcolonial Studies Reader (18-23). London: Routledge.

Levinas, E. (1999). Alterity and Transcendence. London: The Athlone Press.

McGlynn, C. (2010) Flowers and Flow-ers: Antiphallocentric Effects in Ulysses. Otherness: Essays and Studies 1.1 Oct. [Online] Available: http://www.otherness.dk/journal/vol-1/

Piatti-Farnell, L. (2010). A Tour of the Cannibal Quarters: Industrial Fantasies and Carnivorous Appetites in Roald Dahl's Fiction. Otherness: Essays and Studies 1.1 Oct. [Online] Available: http://www.otherness.dk/journal/vol-1/

Ryan, M. (2010). Sounding Different Notes: Approaching the Other through Music in John Carney's film Once. Otherness: Essays and Studies 1.1 Oct. [Online] Available: http://www.otherness.dk/journal/vol-1/

Tynan, M. (2010). Fin-de-siècle Gaelic Gothic: Reflections on the Irish Question. Otherness: Essays and Studies 1.1 Oct. [Online] Available: http://www.otherness.dk/journal/vol-1/

Wolfreys, J., Robins, R., \& Womack, K. (2006). Alterity. Key Concepts in Literary Theory. Edinburgh: Edinburgh University Press. 